\title{
PENGARUH TEAMWORK TERHADAP KINERJA KARYAWAN MELALUI JOB SATISFACTION
}

\author{
Dini Hariani Octavia \\ Universitas Negeri Surabaya \\ dini.17080574096@mhs.unesa.ac.id \\ Budiono \\ Universitas Negeri Surabaya \\ ec.budiono@unesa.ac.id
}

\begin{abstract}
This research aims to examine and analyze the effect of teamwork on employee performance through employees' job satisfaction at PT. Jasa Raharja Cabang Jawa Timur. This research is causality research with a quantitative approach. The population in this research is 159 employees. The sample was collected through a random sampling technique and obtained 62 respondents-the statistical analysis using Partial Least Square with SmartPLS 3.0. The results show that teamwork has a positive and significant influence on employee performance, teamwork has a positive and significant influence on job satisfaction. Job satisfaction has a positive and significant influence on employee performance. Teamwork has no significant influence on employee performance through job satisfaction. Companies can encourage employees to do teamwork by creating teams to complete tasks.
\end{abstract}

Keywords: employee performance; job satisfaction; teamwork.

\section{PENDAHULUAN}

Sumber Daya Manusia (SDM) adalah faktor terpenting dalam perusahaan, tujuan perusahaan bisa tercapai dengan sumber daya manusia yang berkualitas dan memiliki kemampuan dalam suatu pekerjaan yang dilakukan (Samsuni, 2017). Salah satu upaya yang dilakukan perusahaan yaitu dengan meningkatkan kinerja karyawan pada perusahaan. Kinerja karyawan adalah pencapaian yang didapatkan oleh karyawan berdasarkan terselesainya suatu pekerjaan dalam periode waktu tertentu (Widiyanti et al., 2017). Kinerja karyawan juga dapat diartikan bahwa karyawan harus memiliki pencapaian dalam suatu pekerjaan sebagai rasa tanggung jawab terhadap perusahaan (Rismayanti $e t$ al., 2018).

Kinerja karyawan dapat ditingkatkan dengan melakukan kerjasama tim untuk pencapaian yang efektif dan efisien serta terhindar dari karyawan yang menganggur (Arifin, 2020). Dewi et al. (2018), Pandelaki (2018), dan Priskilla \& Santika (2019) menyatakan teamwork memiliki pengaruh secara signifikan positif tehadap kinerja karyawan. Kesenjangan terjadi pada penelitian Silvani \& Triatmanto (2017) bahwa teamwork tidak memiliki pengaruh yang signifikan positif terhadap kinerja karyawan. Menurut Silvani \& Triatmanto (2017), kurangnya rasa kepercayaan terhadap rekan kerja sehingga teamwork tidak dapat meningkatkan kinerja karyawan.

Job satisfaction memiliki peran penting dalam menciptakan karyawan yang berkualitas (Rismayanti et al., 2018). Menurut Noor et al. (2014), kepuasan kerja merupakan sikap yang ditunjukkan oleh karyawan ketika menghadapi dan menyelesaikan suatu pekerjaan sehingga menimbulkan rasa puas. Sari et al. (2019), Setia et al. (2020), dan Sari (2015) mengemukakan job satisfaction berpengaruh signifikan positif terhadap kinerja karyawan. Menurut Kharisma et al. (2019), kepuasan kerja diukur dari pencapaian hasil yang sesuai dengan harapan karyawan, sehingga hal ini menimbulkan suatu kepuasan yang berdampak pada perusahaan.

Penelitian ini dilakukan di PT Jasa Raharja Cabang Jawa Timur, perusahaan yang bergerak pada bidang jasa asuransi sosial yaitu asuransi kecelakaan penumpang alat angkutan umum. Berdasarkan hasil wawancara dengan karyawan bagian Administrasi yang menerangkan sudah terlaksananya 
Dini Hariani Octavia \& Budiono. Pengaruh Teamwork terhadap Kinerja Karyawan melalui Job Satisfaction

teamwork untuk membantu operasional perusahaan antar karyawan dan meningkatkan kinerja karyawan serta job satisfaction. Namun, masih terdapat kendala pada komunikasi yang belum baik serta kurangnya keterbukaan antar karyawan atau anggota tim dalam permasalahan yang ada. Sesuai dengan pengamatan di lapangan yaitu kurangnya komunikasi yang intensif dapat memengaruhi kinerja karyawan. Sehingga, hal ini akan menghambat kinerja karyawan yang dapat menunjang kepuasan karyawan terhadap hasil pekerjaan. Kepuasan kerja yang rendah akan melemahkan tingkat produktivitas karyawan dalam pekerjaan sehingga akan berdampak pada hasil pekerjaan.

Penelitian ini bertujuan untuk menguji dan menganalisis bagaimana pengaruh teamwork terhadap kinerja karyawan, pengaruh teamwork terhadap job satisfaction, pengaruh job satisfaction terhadap kinerja karyawan, serta pengaruh teamwork terhadap kinerja karyawan melalui job satisfaction.

\section{KAJIAN PUSTAKA DAN PENGEMBANGAN HIPOTESIS}

\section{Teamwork}

Priskilla \& Santika (2019) menyatakan teamwork merupakan hal terpenting dalam upaya meningkatkan kualitas kinerja dan menghindari miskomunikasi yang bisa terjadi antar karyawan maupun pimpinan. Selain itu, teamwork perlu dilatih dengan aspek-aspek yang disesuaikan dengan perusahaan. Tim adalah sekumpulan orang yang berdasarkan kemampuan, bekerjasama, dan saling melengkapi untuk mencapai tujuan yang sama (Hanafi, 2016). Tim kerja menghasilkan suatu koordinasi, sehingga sebuah tim harus memberikan kontribusi yang baik dan efektif bagi organisasi atau perusahaan (Silvani \& Triatmanto, 2017). Salah satu gagasan yang dikemukakan Pandelaki (2018), teamwork dilakukan oleh beberapa karyawan yang memiliki kesamaan tujuan dan strategi dalam pencapaian target perusahaan.

Kelemba et al. (2017) mengungkapkan melalui teamwork karyawan dalam perusahaan mampu berbagi banyak hal mengenai pengetahuan dan pengalaman. Teamwork merupakan suatu kegiatan yang dilakukan oleh sejumlah orang dalam suatu perusahaan (Wulandari et al., 2020). Selain itu, Adil \& Hamid (2020) mengemukakan teamwork adalah peluang yang diberikan kepada karyawan untuk berbagi ide-ide terbaik. Teamwork dapat diartikan sebagai sikap karyawan dalam bersaing secara sehat melalui pengalaman dan pemecahan masalah secara tepat sesuai dengan keahlian masingmasing (Widiyanti et al., 2017). Berdasarkan Priskilla \& Santika (2019), indikator teamwork yang terdiri dari delapan indikator yaitu kepemimpinan partisipatif, tanggung jawab, penyamaan tujuan, komunikasi yang intensif, fokus pada masa yang akan datang, fokus pada tugas, pengerahan bakat, dan tanggapan yang cepat.

\section{Job Satisfaction}

Devina (2018) menyatakan job satisfaction adalah bentuk perasaan yang diungkapkan terhadap sebuah pekerjaan yang diselesaikan tanpa memandang pekerjaan mereka, perasaan yang diungkapkan bisa menyenangkan maupun tidak, sehingga menunjukkan rasa kepuasan bagi karyawan. Karyawan akan merasa puas terhadap suatu pekerjaan jika sudah memenuhi aspek pada pekerjaan tersebut dan karyawan berusaha untuk memenuhi aspek tersebut (Hatta \& Musnadi, 2017). Kepuasan merupakan perasaan yang muncul setelah menyelesaikan suatu pekerjaan, perasaan tersebut bisa membuat karyawan merasakan senang maupun tidak senang (Arifin, 2020). Perasaan puas seorang karyawan terhadap pekerjaannya bisa memberikan rasa senang sehingga merasa nyaman dalam bekerja (Probo et al., 2008). Kepuasan kerja seseorang juga tergantung pada harapan dan hasil yang diperoleh dari sebuah pekerjaan (Nur, 2013).

Hidayat et al. (2019) mengartikan kepuasan kerja dapat dirasakan oleh karyawan ketika tingkat loyalitas terhadap pekerjaan itu sendiri tinggi. Setiap individu merasakan tingkat kepuasan yang berbeda-beda hal ini bisa diukur berdasarkan pengawasan dari pimpinan pada tingkat absensi, semangat kerja, dan kendala maupun keluhan dari karyawan tersebut (Kharisma et al., 2016). Kepuasan karyawan merupakan kondisi yang menyenangkan dan membahagiakan terhadap pencapaian pekerjaan (Kesawa et al., 2019). Berdasarkan Dewi et al. (2018), indikator job satisfaction terdiri dari pekerjaan, gaji, kesempatan promosi, rekan kerja, dan kondisi kerja. 


\section{Kinerja Karyawan}

Menurut Silvani \& Triatmanto (2017), kinerja karyawan adalah bagaimana seseorang melakukan pekerjaan dan hasil yang dicapai. Hasil tersebut merupakan prestasi kerja karyawan yang dapat dijadikan untuk menentukan karyawan termasuk dalam tingkat kinerja seperti apa dalam perusahaan. Kinerja karyawan dapat dilihat dan dinilai berdasarkan prestasi yang telah dicapai serta sesuai dengan standar perusahaan (Hidayat et al., 2019). Kinerja karyawan yang kompeten pada perusahaan dapat memberikan pencapaian yang lebih unggul dari pesaing (Priskilla \& Santika, 2019).

Kinerja karyawan bisa diartikan sebagai aset perusahaan yang berguna untuk mengoptimalkan pencapaian perusahaan (Ali \& Wardoyo, 2021). Kinerja karyawan adalah hasil yang diperoleh berdasarkan fasilitas yang didapatkan dari perusahaan dalam menyelesaikan pekerjaan (Noor et al., 2016). Kinerja karyawan dapat diartikan juga sebagai hasil yang diperoleh karyawan berdasarkan tanggung jawabnya (Widiyanti et al., 2017). Kinerja yang dilakukan oleh karyawan dipengaruhi oleh kepuasan yang berdasarkan keterampilan dan sifat-sifat individu (Fauziah \& Kistyanto, 2016). Berdasarkan Priskilla \& Santika (2019), indikator kinerja karyawan yang digunakan dalam penelitian ini terdiri dari kualitas, kuantitas, kebutuhan pengawasan, efektivitas biaya, ketepatan waktu, dan hubungan antar perorangan.

\section{Hubungan antar Variabel}

Hubungan antar variabel dapat diamati pada Gambar 1 kerangka konseptual.

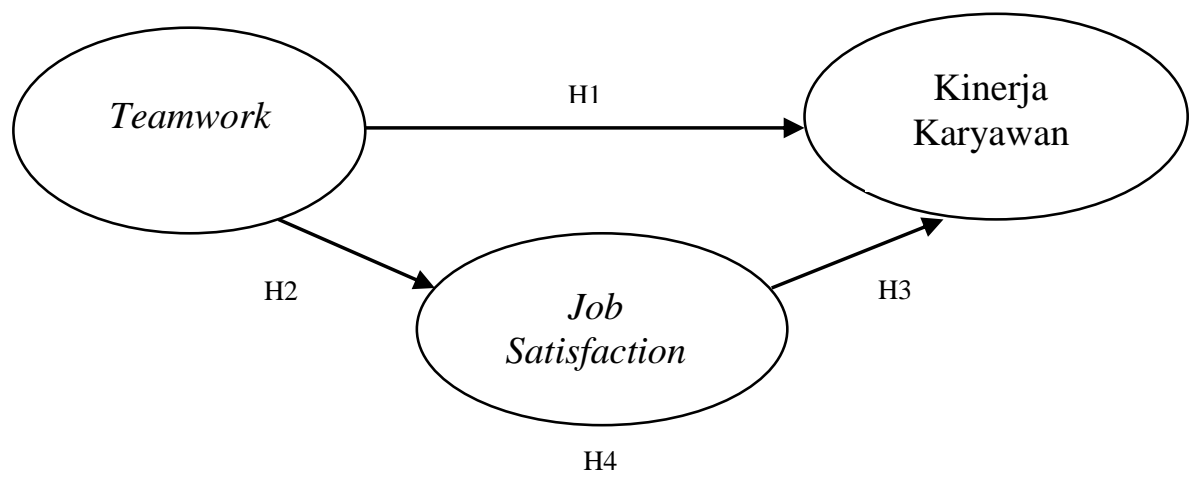

Gambar 1. KERANGKA KONSEPTUAL

Teamwork memiliki peran penting dalam meningkatkan kinerja karyawan, teamwork dapat terjadi dan berhasil jika karyawan mampu untuk berkonsentrasi dan memiliki keahlian untuk menyelesaikan pekerjaan maupun permasalahan (Widiyanti et al., 2017). Teamwork pada perusahaan adalah bentuk koordinasi sehingga kinerja berkelompok lebih memberikan hasil yang maskimal daripada kinerja perseorangan (Silvani \& Triatmanto, 2017). Pendapat ini juga didukung Setia et al. (2020), bahwa teamwork adalah salah satu cara menyelesaikan pekerjaan dengan berkelompok melalui keterampilan dan komitmen sehingga hasil pekerjaan lebih baik dari kinerja individu. Kelemba et al. (2017) menyatakan adanya sebuah tim maka kepatuhan terhadap standar kinerja dapat terlaksana dengan baik. Penelitian Adil \& Hamid (2020), Pandelaki (2018) dan Priskilla \& Santika (2019) membuktikan teamwork memiliki pengaruh positif terhadap kinerja karyawan. Dewi et al. (2018), Hanafi (2016), Adil \& Hamid (2020), dan Panggiki et al. (2017) menyatakan teamwork memiliki pengaruh secara signifikan positif terhadap kinerja karyawan.

H1: Teamwork berpengaruh positif terhadap kinerja karyawan.

Devina (2018) menyatakan dampak teamwork terhadap job satisfaction menunjukkan variabel teamwork memiliki pengaruh positif terhadap job satisfaction. Hasil tersebut disebabkan teamwork memiliki pengaruh besar terhadap prestasi kerja yang baik serta dapat memengaruhi kepuasan kerja seperti upah yang meningkat, peningkatan target, dan memiliki hubungan baik antar karyawan. Berdasarkan Wulandari et al. (2020) peningkatan teamwork akan berdampak pada pencapaian hasil 
Dini Hariani Octavia \& Budiono. Pengaruh Teamwork terhadap Kinerja Karyawan melalui Job Satisfaction

yang maksimal sehingga kepuasan kerja akan meningkat. Peningkatan teamwork juga dapat meningkatkan pengetahuan dan keterampilan yang dimiliki karyawan serta dapat menunjang kepuasan kerja (Hanaysha \& Tahir, 2016). Pendapat serupa juga diungkapkan Arifin (2020), Hatta \& Musnadi (2017), dan Devina (2018) variabel teamwork memiliki pengaruh yang signifikan positif terhadap job satisfaction. Apabila teamwork meningkat maka job satisfaction juga meningkat. Suparno et al. (2020), Ali et al. (2017). Kelemba et al. (2017) memiliki pendapat yang sama bahwa teamwork berpengaruh secara positif terhadap job satisfaction. Dhurup et al. (2016), Kim (2018), dan Ginting \& Siburian (2019) menyatakan bahwa teamwork memiliki pengaruh yang positif terhadap job satisfaction.

\section{$\mathrm{H} 2$ : Teamwork berpengaruh positif terhadap job satisfaction.}

Sari (2015) mengemukakan variabel job satisfaction memiliki pengaruh positif terhadap kinerja karyawan. Hal ini dapat diartikan semakin puas karyawan terhadap kinerjanya maka semakin mampu karyawan tersebut memenuhi tujuan perusahaan. Selain itu, kepuasan karyawan memberikan motivasi kepada karyawan untuk melakukan kinerja yang terbaik pada perusahaan, ketika karyawan merasa puas dengan hasil pekerjaan maka akan meningkatkan kinerjanya (Dewi et al., 2018). Penelitian Dessy \& Sanuddin (2017) menghasilkan kepuasan kerja memiliki pengaruh terhadap kinerja karena manajemen perusahaan mampu memberikan kepuasan berupa gaji yang sesuai serta hubungan antar karyawan. Penelitian ini sesuai dengan Sausan et al. (2016) dan (Rismayanti et al., 2018) bahwa job satisfaction memiliki pengaruh terhadap kinerja karyawan. Hasil ini didukung oleh Nur (2013), Probo et al. (2008), dan Setia et al. (2020) bahwa job satisfaction memiliki pengaruh langsung terhadap kinerja karyawan. Kharisma et al. (2016), Noor et al. (2014), dan Panggiki et al. (2017) mengemukakan pendapat yang serupa bahwa variabel job satisfaction berpengaruh signifikan positif terhadap kinerja karyawan.

\section{H3: Job satisfaction berpengaruh positif terhadap kinerja karyawan.}

Hidayat et al. (2019) mengemukakan jika ingin meningkatkan kinerja karyawan maka diperlukan peningkatan pada kepuasan karyawan yang bisa dilakukan dengan melakukan teamwork yang berkompeten. Selain itu, upaya dalam meningkatkan kepuasan karyawan dan kinerja karyawan maka yang perlu diperhatikan yaitu hasil kerja karyawan yang diukur berdasarkan target dan hasil kerja nyata yang sesuai dengan kebijakan perusahaan. Pendapat ini didukung Arifin (2020) bahwa kerjasama tim memiliki pengaruh langsung terhadap kinerja karyawan melalui kepuasan kerja. Musriha (2013) menyatakan teamwork merupakan cerminan dari manajemen diri, komitmen, kompetensi, dan tanggung jawab yang dimiliki karyawan sehingga dapat memberikan kepuasan diri terhadap pekerjaan serta kinerja yang baik. Hatta \& Musnadi (2017). Masyithah et al. (2018) menyatakan job satisfaction mampu memediasi teamwork terhadap kinerja karyawan. Haqq (2020) menyatakan teamwork pada budaya perusahaan berdampak pada kinerja karyawan yang memberikan kepuasan kepada karyawan. Penelitian Akbar (2019) pada survei kepuasan kerja memberikan hasil bahwa teamwork berpengaruh terhadap kinerja karyawan. Teamwork bersinergi positif terhadap kepuasan kerja untuk menghindari stress kerja sehingga dapat meningkatkan kinerja karyawan (Adi $e t$ al., 2018).

\section{H4: Job satisfaction memediasi pengaruh teamwork terhadap kinerja.}

\section{METODE PENELITIAN}

Jenis penelitian ini adalah penelitian kuantitatif dengan lokasi penelitian di PT. Jasa Raharja Cabang Jawa Timur yang berlokasi di Jl. Diponegoro No. 96-98, Surabaya. Data diperoleh melalui wawancara, pengamatan, dan penyebaran kuesioner. Kuisioner disusun menggunakan Google Form. Pengumpulan data melalui penyebaran kuesioner secara online menggunakan Whatsapp kepada karyawan PT. Jasa Raharja. Item pada kuesioner diukur menggunakan skala likert. Populasi dalam penelitian merupakan seluruh karyawan PT. Jasa Raharja Cabang Jawa Timur sebesar 159 karyawan, dengan sampel menggunakan teknik random sampling yaitu sebesar 62 karyawan. Namun, ketika 
penyebaran kuesioner hanya terdapat 30 responden yang mengisi kuesioner dikarenakan karyawan pada PT. Jasa Raharja Cabang Jawa Timur terdistribusi di seluruh kantor Jawa Timur. Teknik analisis yang digunakan yaitu menggunakan Structural Equation Modelling (SEM) dengan aplikasi Partial Least Square (PLS) versi 3.0.

\section{HASIL DAN PEMBAHASAN}

\section{Karakteristik Responden}

Pada penelitian ini jumlah sampel yaitu 30 responden yang terdiri dari pria berjumlah 14 karyawan $(46,7 \%)$ dan wanita berjumlah 16 karyawan $(53,3 \%)$. Karyawan yang berumur $\leq 30$ tahun berjumlah 14 karyawan (46,6\%), sementara karyawan berumur antara 31-41 tahun berjumlah 14 karyawan $(46,6 \%)$, dan karyawan berumur antara $42-51$ tahun berjumlah 2 karyawan $(6,6 \%)$. Karyawan dengan jenjang pendidikan SMA berjumlah 5 karyawan $(16,7 \%)$, karyawan dengan jenjang pendidikan D3 berjumlah 5 karyawan $(16,7 \%)$, karyawan dengan jenjang pendidikan S1 berjumlah 19 karyawan $(63,3 \%)$, karyawan dengan jenjang pendidikan S2 berjumlah 1 karyawan $(3,3 \%)$. Selanjutnya, untuk karyawan dengan masa kerja selama rentang waktu $\leq 5$ tahun berjumlah 10 karyawan $(33,3 \%)$, kemudian karyawan yang bekerja selama rentang waktu antara 6-10 tahun berjumlah 14 karyawan (46,6\%), dan karyawan yang telah bekerja selama rentang waktu antara 11-15 tahun sebanyak 3 karyawan (10\%). Selanjutnya, karyawan yang bekerja selama rentang waktu $>16$ tahun sebanyak 3 karyawan $(10 \%)$.

Penelitian ini menggunakan three box method untuk penilaian mean jawaban responden di mana angka paling rendah adalah 1 dan paling tinggi adalah 5. Adapun penjelasannya mean penilaian indikator variabel teamwork yaitu sebanyak 4,19 untuk kepemimpinan partisipatif, sebesar 4,57 untuk tanggung jawab, sebanyak 4,30 untuk penyamaan tujuan, sebanyak 4,55 untuk komunikasi yang intensif, sebanyak 4,30 untuk fokus pada masa yang akan datang, dan sebanyak 4,50 untuk fokus pada tugas, sebanyak 4,67 untuk pengerahan bakat, dan sebanyak 4,27 untuk tanggapan yang cepat dengan mean variabel sebesar 4,42 tergolong kategori tinggi. Nilai mean indikator dari job satisfaction yakni sebanyak 4,30 untuk pekerjaan itu sendiri, sebanyak 4,33 untuk gaji, sebanyak 4,17 untuk kesempatan promosi, sebanyak 4,53 untuk rekan kerja, dan sebanyak 4,43 untuk kondisi kerja dengan mean variabel sebesar 4,35 yang tergolong kategori tinggi. Adapun indikator kinerja karyawan di antaranya kualitas sebanyak 4,33, kuantitas sebanyak 4,37, kebutuhan pengawasan sebanyak 4,30, efektivitas biaya sebanyak 4,37, ketepatan waktu sebanyak 4,27, dan hubungan antar perorangan sebanyak 4,27 dengan mean variabel sebanyak 4,32 yang tergolong kategori tinggi.

\section{Convergent Validity}

Hasil nilai korelasi dari seluruh indikator jika melebihi 0,70 dapat dikatakan valid. Gambar 2 menunjukkan setiap variabel yang dijelaskan oleh masing-masing indikator telah memenuhi syarat yaitu nilai outer loading > 0,50 dan dinyatakan valid (Gozhali \& Latan, 2015).

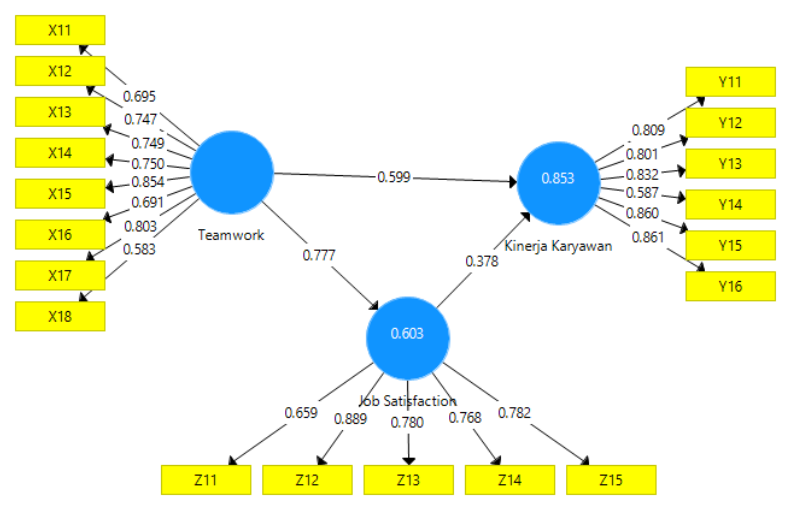

Sumber: output SmartPLS 3.0 (2021)

Gambar 2. UJI MEASUREMENT MODEL 
Dini Hariani Octavia \& Budiono. Pengaruh Teamwork terhadap Kinerja Karyawan melalui Job Satisfaction

\section{Composite Reliability \& Cronbach's Alpha}

Berdasarkan Tabel 1, nilai composite reliability masing-masing variabel yaitu variabel teamwork memiliki nilai 0,904 ; variabel job satisfaction memiliki nilai 0,884 ; dan variabel kinerja kayawan nilai sebesar 0,912. Keseluruhan variabel memiliki reliabilitas yang baik karena di atas 0,70.

Tabel 1.

\section{COMPOSITE RELIABILITY DAN CRONBACH'S ALPHA}

\begin{tabular}{ccc}
\hline Variabel & Composite Reliability & Cronbach's Alpha \\
\hline Teamwork & 0,904 & 0,878 \\
Job Satisfaction & 0,884 & 0,834 \\
Kinerja Karyawan & 0,912 & 0,882
\end{tabular}

Sumber: Output SmartPLS 3.0 (2021, data diolah)

\section{Analisis R-Square}

Nilai $R$-Square pada Tabel 2 menjelaskan model pengaruh teamwork terhadap job satisfaction menghasilkan nilai 0,603. Artinya job satisfaction mampu dijelaskan oleh variabel teamwork sebesar $60,3 \%$, sedangkan sebesar 39,7\% dijelaskan oleh variabel-variabel lain di luar penelitian ini. Model pengaruh teamwork terhadap kinerja karyawan menghasilkan nilai 0,853 . Artinya, variabel konstruk kinerja karyawan mampu dijelaskan oleh variabel teamwork sebesar $85,3 \%$, serta nilai sebesar $14,7 \%$ dijelaskan oleh variabel-variabel lain yang tidak termasuk dalam penelitian ini.

Tabel 2.

\section{$R-S Q U A R E$}

\begin{tabular}{cc}
\hline Variabel & R-Square \\
\hline Job Satisfaction & 0,603 \\
Kinerja Karyawan & 0,853 \\
\hline Sumber: Output SmartPLS 3.0 (2021, data diolah)
\end{tabular}

\section{Uji Relevensi Prediksi}

Model PLS juga dapat dievaluasi dengan melihat nilai $Q$-Square predictive relevance, perhitungan $Q$ Square predictive relevance dapat dilihat pada rumus (1). Hasil perhitungan diperoleh sebesar 0,78 dan lebih dari 0 . Model memiliki predictive relevance yang dapat menjelaskan model sebesar $78 \%$.

$$
\begin{aligned}
& Q^{2}=1-(\sqrt{1-R 12}) \times \sqrt{1-R 22} \\
& Q^{2}=1-(\sqrt{1-0,6032}) \times(\sqrt{1-0,8532}) \\
& Q^{2}=1-(\sqrt{0,636} \times \sqrt{0,272}) \\
& Q^{2}=1-(0,797 \times 0,522) \\
& Q^{2}=0,78 \ldots \ldots \ldots \ldots \ldots \ldots \ldots \ldots \ldots \ldots \ldots \ldots \ldots \ldots \ldots \ldots \ldots \ldots
\end{aligned}
$$

\section{Uji Kausalitas}

Tabel 3.

PATH COEFICIENTS \& INDIRECT EFFECT

\begin{tabular}{lcccc}
\hline \multicolumn{1}{c}{ Hubungan Variabel } & $\begin{array}{c}\text { Original } \\
\text { Sample }\end{array}$ & $\begin{array}{c}T \text { - } \\
\text { Statistics }\end{array}$ & \multicolumn{2}{c}{ Keterangan } \\
\hline Teamwork $\rightarrow$ Job Satisfaction & 0,777 & 9,609 & $\geq 1,96$ (Signifikan) & Diterima \\
Teamwork $\rightarrow$ Kinerja Karyawan & 0,599 & 3,549 & $\geq 1,96$ (Signifikan) & Diterima \\
Job Satisfaction $\rightarrow$ Kinerja Karyawan & 0,378 & 2,118 & $\geq 1,96$ (Signifikan) & Diterima \\
Teamwork $\rightarrow$ Job Satisfaction $\rightarrow$ & 0,293 & 1,846 & $\leq 1,96$ (Signifikan) & Ditolak \\
Kinerja Karyawan & & &
\end{tabular}

Sumber: Output SmartPLS 3.0 (2021) 


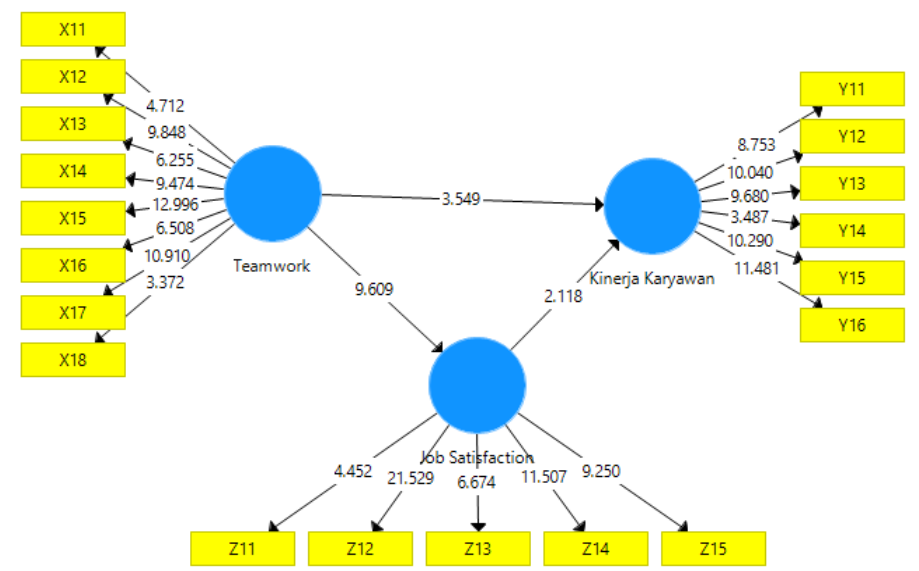

Sumber: Hasil uji SmartPLS 3.0 (2021)

\section{Gambar 3. UJI MEASUREMENT BOOSTRAPING MODEL}

Berdasarkan Tabel 3, nilai $t$-statistics pengaruh teamwork terhadap job satisfaction sebesar 9,609 $\geq$ 1,96. Hal ini menunjukkan variabel teamwork terhadap job satisfaction memiliki pengaruh yang signifikan. Sedangkan nilai original sample yaitu sebesar 0,777 yang memiliki tanda positif yang berarti apabila semakin bertambah nilai teamwork maka job satisfaction akan meningkat pula. Hal ini bermakna bahwa berbanding lurus.

Dampak pengaruh teamwork terhadap kinerja karyawan dilihat berdasarkan nilai $t$-statistics sebesar $3,549 \geq 1,96$. Hal tersebut menjelaskan adanya pengaruh yang signifikan pada variabel teamwork terhadap kinerja karyawan. Sedangkan nilai original sample yaitu sebesar 0,599 yang memiliki tanda positif yang berarti apabila bertambah teamwork maka kinerja karyawan akan semakin meningkat pula. Hal ini bermakna bahwa berbanding lurus.

Dampak pengaruh job satisfaction terhadap kinerja karyawan dilihat berdasarkan nilai $t$-statistics sebesar $2,118 \geq 1,96$. Hal ini menjelaskan variabel job satisfaction terhadap kinerja karyawan memiliki pengaruh yang signifikan. Sedangkan nilai koefisien estimate yang dilihat berdasarkan original sample yaitu sebesar 0,378 yang memiliki hasil positif yang berarti jika semakin bertambah job satisfaction maka kinerja karyawan akan semakin tinggi.

Besarnya koefisien tidak langsung dilihat pada original sample sebesar 0,293 dan tidak signifikan pada 5\% (t hitung $\leq \mathrm{t}$ tabel 1,96 ) pada variabel teamwork terhadap kinerja karyawan melalui job satisfaction. Hal tersebut menjelaskan teamwork memiliki pengaruh langsung terhadap kinerja karyawan namun tidak memiliki pengaruh secara langsung dengan kinerja karyawan melalui job satisfaction.

\section{Pengaruh Teamwork terhadap Kinerja Karyawan}

Hasil analisis PLS menunjukkan jika teamwork berpengaruh terhadap kinerja karyawan sehingga $\mathrm{H} 1$ diterima. Wawancara dilakukan pada beberapa karyawan PT. Jasa Raharja Cabang Jawa Timur menjelaskan bahwa perusahaan telah menerapkan teamwork dengan baik sehingga menimbulkan dampak positif pada kinerja karyawan. Setiap karyawan memiliki suatu target pada setiap tim untuk diselesaikan sesuai dengan kemampuan dan pembagian tugas yang ada. Adanya teamwork tujuan perusahaan akan tercapai karena setiap bagian memiliki tujuan akhir yang sama. Sehingga, pada PT. Jasa Raharja Cabang Jawa Timur teamwork dapat dikatakan sudah baik dan meningkatkan kinerja karyawan pada perusahaan.

Hasil penelitian membuktikan kinerja karyawan dipengaruhi secara positif dan signifikan oleh teamwork. Sehingga, karyawan telah menerapkan teamwork untuk mendukung kinerja dengan baik dan optimal. Hal ini disebabkan oleh rasa tanggung jawab yang dimiliki oleh karyawan terhadap pekerjaannya sehingga mampu menghasilkan kinerja yang sesuai. Hasil ini mendukung penelitian 
Dini Hariani Octavia \& Budiono. Pengaruh Teamwork terhadap Kinerja Karyawan melalui Job Satisfaction

Dewi et al. (2018), Pandelaki (2018), Priskilla \& Santika (2019) bahwa teamwork berpengaruh secara signifikan positif tehadap kinerja karyawan. Hasil penelitian ini juga sesuai dengan Adil \& Hamid (2020), Widiyanti et al. (2017), Hanafi (2016), Kelemba et al. (2017) mengemukakan teamwork memiliki pengaruh secara signifikan positif terhadap kinerja karyawan. Namun, adanya kesenjangan pada Silvani \& Triatmanto (2017) yang mengungkapkan teamwork tidak berpengaruh signifikan positif terhadap kinerja karyawan.

\section{Pengaruh Teamwork terhadap Job Satisfaction}

Teamwork memiliki pengaruh pada job satisfaction jika dilihat dari hasil penelitian sehingga $\mathrm{H} 2$ diterima. Artinya, ketika tingkat teamwork semakin tinggi maka job satisfaction semakin tinggi begitu sebaliknya. Teamwork dapat memengaruhi job satisfaction karena semakin tinggi teamwork yang dijalankan perusahaan maka akan meningkatkan tingkat kepuasan karyawan pada pekerjaan yang dijelaskan. Teamwork yang sesuai dengan tujuan perusahaan akan meningkatkan kepuasan kerja seperti gaji atau upah yang diperoleh dari peningkatan target secara tim, hubungan rekan kerja yang baik, serta peluang untuk promosi jabatan.

Berdasarkan hasil wawancara pada beberapa karyawan PT. Jasa Raharja Cabang Jawa Timur bahwa teamwork sudah dilakukan berdasarkan tingkat kepuasan yang diketahui melalui evaluasi kerja secara berkala. Evaluasi kerja yang dilakukan bisa berdasarkan hasil yang dicapai dan dilakukan oleh pimpinan perusahaan. Hal ini tentunya memudahkan perusahaan dalam memberikan penilaian yang sesuai dengan hasil kerja tim. Hasil penelitian ini membuktikan teamwork dipengaruhi secara signifikan positif terhadap job satisfaction. Hasil ini mendukung penelitian Wulandari et al. (2020), Arifin (2020), dan Kelemba et al. (2017) bahwa teamwork berpengaruh secara signifikan positif terhadap job satisfaction. Adapun hasil penelitian Hatta \& Musnadi (2017), Hanaysha \& Tahir (2016), dan Devina (2018) mengemukakan teamwork memiliki pengaruh signifikan positif terhadap job satisfaction. Ali et al. (2017) dan Suparno et al. (2020) mengemukakan teamwork memiliki pengaruh langsung pada kinerja karyawan.

\section{Pengaruh Job Satisfaction terhadap Kinerja Karyawan}

Hasil penelitian menunjukkan jika job satisfaction memengaruhi kinerja karyawan PT. Jasa Raharja Cabang Jawa Timur sehingga H3 diterima. Artinya, semakin meningkat job satisfaction maka akan semakin tinggi kinerja karyawan begitu sebaliknya. Job satisfaction dapat memengaruhi hasil dari pencapaian karyawan sesuai dengan keinginan karyawan dan kebutuhan PT. Jasa Raharja Cabang Jawa Timur.

Seperti yang dijelaskan sebelumnya, hasil wawancara pada beberapa karyawan PT. Jasa Raharja Cabang Jawa Timur tingkat kepuasan karyawan diperoleh berdasarkan hasil kerja yang dicapai apakah sudah sesuai dengan yang diharapkan karyawan maupun perusahaan, sehingga perusahaan dapat mengambil langkah untuk memberikan penghargaan kepada karyawan tersebut bisa berupa gaji maupun promosi jabatan. Hasil ini mendukung penelitian Kharisma et al. (2016), Panggiki et al. (2017), dan Sari (2015) bahwa job satisfaction berpengaruh signifikan positif terhadap kinerja karyawan. Dewi et al. (2018), Setia et al. (2020), Noor et al. (2014) mengemukakan job satisfaction memiliki pengaruh secara langsung terhadap kinerja karyawan. Hasil ini juga didukung Sari et al. (2019) dan Nur (2013) yang menyatakan adanya pengaruh job satisfaction terhadap kinerja karyawan.

\section{Pengaruh Teamwork terhadap Kinerja Karyawan}

Hasil penelitian menunjukkan teamwork berpengaruh langsung terhadap kinerja karyawan, tetapi tidak memiliki pengaruh secara langsung terhadap kinerja karyawan melalui job satisfaction sehingga H4 ditolak. Karyawan PT. Jasa Raharja dapat meningkatkan kinerjanya dengan cara meningkatkan teamwork. Karyawan yang bekerja dalam teamwork akan memberikan konstribusinya berupa kemampuan dan keahlian yang sesuai dengan pekerjaan dan pembagian tugas pada teamwork tersebut untuk meningkatkan kinerjanya tanpa memedulikan job satisfaction. Hal ini dikarenakan hubungan yang terjadi antara teamwork dengan kinerja karyawan adalah hubungan langsung, maka pengaruh variabel job satisfaction di dalam hubungan antara teamwork terhadap kinerja karyawan diabaikan 
atau dihapuskan. Hasil ini mendukung Hatta \& Musnadi (2017) yang menyatakan job satisfaction tidak memediasi pengaruh teamwork terhadap kinerja karyawan.

\section{KESIMPULAN}

Berdasarkan uraian hasil analisis dapat diambil kesimpulan bahwa teamwork secara signifikan positif berpengaruh pada kinerja karyawaan, teamwork secara signifikan positif memengaruhi job satisfaction, job satisfaction secara signifikan positif memengaruhi kinerja karyawan, dan teamwork tidak memiliki pengaruh secara signfikan terhadap kinerja karyawan melalui job satisfaction.

Penelitian ini memberikan saran praktis berdasarkan hasil analisis statistik, pengamatan, dan hasil wawancara yaitu menyarankan perusahaan untuk memberikan pengarahan dan pelatihan terhadap tugas pada sebuah tim supaya karyawan paham mengenai tujuan dan fokus yang harus diselesaikan oleh sebuah tim tersebut. Saran ini akan meningkatkan kinerja karyawan yang dapat menciptakan rasa tangung jawab terhadap sebuah tim beserta tugasnya. Kebutuhan pengawasan, gaji, dan kesempatan promosi merupakan hal yang memiliki faktor penting dalam meningkatkan kinerja karyawan. Perusahaan dapat mengambil langkah dengan melakukan pengawasan secara berkala terhadap karyawan dan memberikan suatu pengahargaan atas pencapaian karyawan yang sesuai dengan harapan perusahaan berupa penambahan gaji maupun promosi jabatan. Sehingga, karyawan PT. Jasa Raharja Cabang Jawa Timur akan merasa senang dan puas ketika suatu pekerjaan yang terselesaikan sesuai harapan diberikan penghargaan dan akan memicu peningkatan kinerja karyawan. Selain itu, melakukan suatu kegiatan bersama secara rutin yang melibatkan seluruh karyawan dapat mempererat hubungan antar karyawan PT. Jasa Raharja Cabang Jawa Timur misalnya kegiatan sosial dan gathering.

Penelitian ini memiliki keterbatasan dari penggunaan sampel yang disebabkan karyawan pada PT. Jasa Raharja Cabang Jawa Timur terdistribusi ke berbagai wilayah di Jawa Timur. Penelitian selanjutnya dapat menggunakan sampel dan objek perusahaan lain sehingga gambaran yang didapat lebih komprehensif. Penelitian ini juga dapat dikembangkan dengan cara menambah variabel lain seperti motivasi kerja, disiplin kerja, dan budaya kerja.

\section{DAFTAR PUSTAKA}

Adi, S. T., Aju, B. I., \& Ayu, B. I. (2018). Effect of Cometence, Leader-Member Exchange and Teamwork on Work Discipline, Job Stress and Their Impact on Employee Performance of Construction Company in East Java, Indonesia. RJOAS, 2(74), 67-78. https://doi.org/https://doi.org/10.18551/rjoas.2018-02.12

Adil, M. S., \& Hamid, K. B. A. (2020). Effect of Teamwork on Employee Performance in High-Tech Engineering SMEs of Pakistan: A Moderating Role of Supervisor Support. South Asian Journal of Management Sciences, 14(1), 122-141. https://doi.org/10.21621/sajms.2020141.07

Akbar, M. D. (2019). Pengaruh Budaya Organisasi terhadap Kinerja Karyawan dengan Kepuasan Kerja sebagai Variabel Mediator. YKPN, 8(5), 55. http://repository.stieykpn.ac.id/558/

Ali, A., Huang, J., Ali, Z., \& Li, Z. (2017). The Effects of Empowerment, Training, and Teamwork on Employee Job Satisfaction: Case of the Agricultural Manufacturing Sector in Khyber Pakhtunkhwa Province, Pakistan. International Conference on Education, Economics and Management Research, 95, 32-39. https://doi.org/10.2991/iceemr-17.2017.9

Ali, F., \& Wardoyo, D. T. W. (2021). Pengaruh Self Efficacy terhadap Kinerja Karyawan dengan Kepuasan Kerja sebagai Variabel Intervening (Studi PT. Ultrajaya Milk Industry, Tbk Surabaya Bagian Marketing). Jurnal Ilmu Manajemen, 9(1), 367-379. https://journal.unesa.ac.id/index.php/jim/article/view/11678 
Dini Hariani Octavia \& Budiono. Pengaruh Teamwork terhadap Kinerja Karyawan melalui Job Satisfaction

Arifin, A. (2020). Pengaruh Kepemimpinan dan Kerja Sama Tim terhadap Kepuasan Kerja dan Kinerja Karyawan. Ekonomi Dan Bisnis, Universitas Bahaudin Mudhary, Madura, 17(2), 186193. http://journal.feb.unmul.ac.id/index.php/KINERJA/article/view/7400

Devina, G. (2018). Pengaruh Teamwork terhadap Kepuasan Kerja Karyawan pada PT. Federal International Finance Cabang Surabaya 2. Jurnal Ilmu Manajemen (JIM), 6(1), 1-9. https://jurnalmahasiswa.unesa.ac.id/index.php/jim/article/view/22457

Dewi, C., Bagia, W., \& Susila, G. (2018). Pengaruh Stres Kerja dan Kepuasan Kerja terhadap Kinerja Karyawan pada Bagian Tenaga Penjualan UD Surya Raditya Negara. Bisma: Jurnal Manajemen, 4(2), 154-161. https://ejournal.undiksha.ac.id/index.php/BISMA$\mathrm{JM} /$ article/view/22015

Dewi, S. K., Sutopo, \& Rahmasari, A. (2018). Pengaruh Teamwork, Dispilin Kerja dan Loyalitas terhadap Kinerja Karyawan pada PT. Amertha Lintas Persada di Surabaya. Jurnal Manajemen Branchmarck, 4(3), 448-456. http://fe.ubhara.ac.id/ojs/index.php/ebranchmarck/article/view/684

Dhurup, M., Surujlal, J., \& Kabongo, D. M. (2016). Finding Synergic Relationships in Teamwork, Organizational Commitment and Job Satisfaction: A Case Study of a Construction Organization in a Developing Country. Procedia Economics and Finance, 35(2016), 485-492. https://doi.org/10.1016/s2212-5671(16)00060-5

Fauziah, F. A., \& Kistyanto, A. (2016). Pengaruh Persepsi Keadilan Distributif pada Penilaian Kinerja terhadap Kinerja Karyawan yang Dimediasi oleh Kepuasan Penilaian Kinerja di PT. Dok dan Perkapalan Surabaya. Jurnal Ekonomi Bisnis Dan Kewirausahaan, 5(1), 1-23. https://doi.org/10.26418/jebik.v5i1.16179

Ginting, A. K., \& Siburian, T. A. (2019). The Effect of Academic Supervision and Teamwork on Work Satisfaction of Public High School Teacher in Binjai City. International Journal of Education and Reasearch, 7(6), 335-346. http://ijern.com/journal/2019/June-2019/29.pdf

Gozhali, I. ., \& Latan, H. (2015). Partial Least Squares Konsep, Teknik dan Aplikasi Menggunakan Program SmartPLS 3.0 Untuk Penelitian Empiris. Semarang: Badan Penerbit Universitas Diponegoro.

Hanafi, A. (2016). The Influence of Competence And Teamwork on Employees Performance of Agriculture, Crops and Horticulture Service, South Sumatera Province. Jurnal Manajemen Dan Bisnis Sriwijaya, 14(2), 235-256. https://doi.org/10.29259/jmbs.v14i2.4005

Hanaysha, J., \& Tahir, P. R. (2016). Examining the Effects of Employee Empowerment, Teamwork, and Employee Training on Job Satisfaction. Procedia - Social and Behavioral Sciences, 219(2016), 272-282. https://doi.org/10.1016/j.sbspro.2016.05.016

Haqq, N. (2020). Pengaruh Budaya Organisasi terhadap Kinerja Karyawan melalui Motivasi sebagai Variabel Intervening Studi pada PT. Rahmat Jaya Perkasa Sidoarjo. Bisma - Bisnis Dan Manajemen, 9(1), 56-68. https://doi.org/Bisnis dan Manajemen

Hatta, M., \& Musnadi, S. (2017). Pengaruh Gaya Kepemimpinan, Kerjasama Tim dan Kompensasi terhadap Kepuasan Kerja serta Dampaknya pada Kinerja Karyawan PT. PLN (Persero) Wilayah Aceh. Jurnal Magister Manajemen, $1(1), \quad 70-80$. http://www.jurnal.unsyiah.ac.id/JMM/article/view/9268

Hidayat, S., Lubis, A. R., \& Majid, M. (2019). Pengaruh Gaya Kepemimpinan, Kerjasama Tim dan Kompensasi terhadap Kinerja Karyawan melalui Kepuasan Kerja pada PT. Dunia Barusa 
Banda Aceh. Jurnal Perspektif Ekonomi Darussalam, 5(1), 86-100. https://doi.org/10.24815/jped.v5i1.14088

Kelemba, J., Chepkilot, R., \& Zakayo, C. (2017). Influence of Teamwork Practices on Employee Performance in Public Service in Kenya. African Research Journal of Education and Social Sciences, 4(3), 1-9. http://www.arjess.org/social-sciences-research/influence-of-teamworkpractices-on-employee-performance-in-public-service-in-kenya.pdf

Kesawa, A. H., Fatmawati, I. K., Puspitasari, D. P., Prastyo, B., \& Fazlurrahman, H. (2019). The Effect of Psychological Well-Being and Psychological Empowerment on Job Satisfaction in Intitusion X. International Journal of Advances in Management and Economics, 8(6), 11-15. https://doi.org/10.31270/ijame/v08/i06/2019/2

Kharisma, M., Prasilowati, S. L., \& Ayuningtyas, E. A. (2016). Pengaruh Budaya Organisasi dan Kepuasan Kerja terhadap Kinerja Karyawan dengan Komitmen Organisasi sebagai Variabel Intervening. Jurnal Ilmu Dan Riset Manajemen, 5(1), 1-20. https://doi.org/10.33370/jpw.v21i2.342

Kim, J.-H. (2018). Effects of Team Leadership Behavior of SME Organization on Teamwork and Job Satisfaction. Journal of Convergence for Information Technology, 8(2), 105-112. http://www.dbpia.co.kr/Journal/articleDetail?nodeId=NODE09012882

Masyithah, S. M., Adam, M., \& Tabran, M. (2018). Analisis Pengaruh Kompensasi, Kerjasama Tim dan Budaya Organisasi terhadap Kepuasan Kerja serta Dampaknya pada Kinerja Karyawan PT. Bank Muamalat Cabang Banda Aceh. Simen, 9(1), 50-59. http://jurnal.stiesabang.ac.id/index.php/simen/article/view/85

Musriha. (2013). Influence of Teamwork, Environment on Job Satisfaction and Job Performance of the Cigarette Rollers at Clove Cigarette Factories in East Java, Indonesia. Developing Country Studies, 3(2), 32-41. https://www.iiste.org/Journals/index.php/DCS/article/view/4252

Noor, N., Rahardjo, K., \& Ruhana, I. (2016). Pengaruh Stres Kerja dan Kepuasan Kerja terhadap Kinerja Karyawan pada PT. Jasa Raharja (Persero) Cabang Jawa Timur Surabaya. Jurnal Administrasi Bisnis, 31(1), 9-15. http://administrasibisnis.studentjournal.ub.ac.id/index.php/jab/article/view/1206

Nur, S. (2013). Konflik, Stress Kerja dan Kepuasan Kerja Pengaruhnya terhadap Kinerja Pegawai pada Universitas Khairun Ternate. Jurnal EMBA: Jurnal Riset Ekonomi, Manajemen, Bisnis Dan Akuntansi, 1(3), 739-749. https://doi.org/10.1109/siu.2009.5136498

Pandelaki, M. T. (2018). Pengaruh Teamwork dan Budaya Kerja terhadap Kinerja Karyawan Yayasan Titian Budi Luhur di Kabupaten Parigi Moutong. Katalogis, 6(5), 35-46. http://jurnal.untad.ac.id/jurnal/index.php/Katalogis/article/view/11414

Panggiki, A. C., Lumanauw, B., Lumintang, G. G., Manajemen, J., Sam, U., \& Manado, R. (2017). Pengaruh Kompensasi, Kerjasama Tim dan Kepuasan Kerja terhadap Kinerja Karyawan pada Ajb Bumiputera 1912 Cabang Sam Ratulangi. Jurnal EMBA: Jurnal Riset Ekonomi, Manajemen, Bisnis Dan Akuntansi, 5(3), 3018-3027. https://doi.org/10.35794/emba.v5i3.17302

Priskilla, N. M., \& Santika, I. P. (2019). Implikasi Gaya Kepemimpinan Transformasional, Iklim Organisasi dan KerjasamaTim terhadap Kinerja Karywan di Puri Saron Hotel Seminyak. $\begin{array}{llll}\text { Journal } O F \quad \text { Applied } & \text { Management }\end{array}$ http://jamms.triatmamulya.ac.id/index.php/JAMMS/article/view/9

Probo, R., Dan, T., \& Kartika, A. (2008). Pengaruh Komitmen Organisasional dan Profesional 
Dini Hariani Octavia \& Budiono. Pengaruh Teamwork terhadap Kinerja Karyawan melalui Job Satisfaction

terhadap Kepuasan Kerja Auditor dengan Motivasi sebagai Variabel Intervening (Studi Empiris pada Kantor Akuntan Publik di Semarang). Jurnal Bisnis Dan Ekonomi (JBE), 15(1), 80-90. https://unisbank.ac.id/ojs/index.php/fe3/article/view/303

Rismayanti, R. D., Musadieq, M. Al, \& Aini, E. K. (2018). Pengaruh Kepuasan Kerja terhadap Turnover Intention serta Dampaknya pada Kinerja Karyawan. Jurnal Administrasi Bisnis, 61(2), 127-136. http://administrasibisnis.studentjournal.ub.ac.id/index.php/jab/article/download/2581/2975

Samsuni. (2017). Manajemen Sumber Daya Manusia. Jurnal Ilmiah Keislaman dan kemasyarakatan, 17(31), 113-124. http://ejurnal.staialfalahbjb.ac.id/index.php/alfalahjikk/article/view/19

Sanuddin, F. D., \& Widjojo, A. (2013). Pengaruh Kepuasan Kerja dan Motivasi Kerja terhadap Komitmen Karyawan. MODUS, 25(2), 217-231. https://doi.org/10.32734/psikologia.v11i3.15782

Sari, N. P., Bendesa, I. K., \& Antara, M. (2019). The Influence of Quality of Work Life on Employees' Performance with Job Satisfaction and Work Motivation as Intervening Variables in Star-Rated Hotels in Ubud Tourism Area of Bali. Journal of Tourism and Hospitality Management, 7(1), 74-83. https://doi.org/10.15640/jthm.v7n1a8

Sari, O. R. (2018). Pengaruh Kepuasan dan Motivasi Kerja terhadap Kinerja Karyawan dengan Organizational Citizenship Behavior (OCB) sebagai Variabel Intervening. Management Analysis Journal, 64(1), 28-35. https://doi.org/10.15294/maj.v4i1.7221

Sausan, N. S., Nasution, A. M. U., \& Sabrina, H. (2016). Pengaruh Kepuasan Kerja dan Loyalitas Karyawan terhadap Kinerja Karyawan Foods Manufacture. E-Journal Bisma Universitas Pendidikan Ganesha, 4(1), 1-8. https://doi.org/10.34007/ebmsj.v1i1.3

Setia, A., Marnis, \& Garnasih, R. (2020). Analisis Pengaruh Pelatihan, Kepuasan Kerja, dan Teamwork terhadap Kinerja Karyawan dengan Kepemimpinan sebagai Variabel Moderasi pada PT. Perkebunan Nusantara V (PTPN V) Pekanbaru. Jurnal Ilmiah Manajemen, 8(2), 202-215. http://www.ejournal.pelitaindonesia.ac.id/ojs32/index.php/PROCURATIO/article/view/632

Silvani, E., \& Triatmanto, B. (2017). Pengaruh Komunikasi, Motivasi dan Kerjasama Tim terhadap Peningkatan Kinerja Karyawan. Jurnal Manajemen Dan Kewirausahaan, 5(1), 47-57. http://eprints.unmer.ac.id/349/

Suparno, Sutjipto, \& Suryadi. (2020). The Effect of Teamwork and Trust on Job Satisfaction of The Teachers of The State High School in Bekasi City. International Journal of Education, Information Technology and Others, 3(1), 92-99. https://doi.org/10.5281/zenodo.3750973

Widiyanti, E., Suprayitno, \& Sutarno. (2017). Pengaruh Teamwork dan Loyalitas terhadap Kinerja Karyawan dengan Kepemimpinan sebagai Variabel Moderasi. Jurnal Ekonomi Dan Kewirausahaan, 17(3), 407-416. http://ejurnal.unisri.ac.id/index.php/Ekonomi/article/view/1857

Wulandari, N. L., Sumadi, N. K., \& Swara, N. N. A. (2020). Pengaruh Self Esteem, Empowerment, dan Team Work terhadap Kepuasan Kerja Karyawan pada PT. BPR TISH di Gianyar. Jurnal Widya Manajemen, 2(1), 89-99. https://doi.org/10.32795/widyamanajemen.v2i1.552 